\title{
COMPETITIVENESS OF SMALL AND MEDIUM ENTERPRISES IN THE BRICS COUNTRIES AND SERBIA
}

\section{Dubravka Skunca}

"Union-Nikola Tesla" University, Faculty of Business and Law, Belgrade, Serbia

\section{Milanka Bogavac}

"Union-Nikola Tesla" University, Faculty of Business and Law, Belgrade, Serbia

\section{Danilo Rudic}

"Union-Nikola Tesla” University, Faculty of Business and Law, Belgrade, Serbia

OMESTE

JEL Category: F12, F21, M21

\begin{abstract}
The focus of this study is on the position of BRICS countries (Brazil, Russia, India, China and South Africa) and Serbia in The Global Competitiveness Report for 2017. Constraints related to the public trust in politicians, the burden of government regulation and hiring and firing practices have caused Brazil to have the lowest rank in the examined group of countries. The highest rank has China (27th place), followed by Russia (38 th place), India (40 th place), South Africa (61st place), Serbia (78 th place) and Brazil (80 th place). Global Competitiveness Report (GCR) indicators related to the small and medium enterprises (SMEs) can be found in 6th pillar of competitiveness Goods market efficiency (effectiveness of anti-monopoly policy, no. procedures to start a business and no. days to start a business), in $7^{\text {th }}$ pillar of competitiveness Labor market efficiency (cooperation in labor-employer relations, flexibility of wage determination, hiring and firing practices, pay and productivity and reliance on professional management), in $9^{\text {th }}$ pillar of competitiveness Technological readiness (firm-level technology absorption) and in $11^{\text {th }}$ pillar of competitiveness Business sophistication (local supplier quantity, local supplier quality, state of cluster development, production process sophistication, extent of marketing and willingness to delegate authority). China has the highest position among examined countries in terms of indicators related to the small and medium enterprises.
\end{abstract}

Keywords: China, Russia, competitiveness, small and medium-sized enterprises

Address of the corresponding author:

Dubravka Skunca

㭋”d dubravkaskunca@hotmail.com 


\section{INTRODUCTION}

The importance of improving national competitiveness is connected with the standard of living as the basis for national prosperity (Savic, 2012). Competitiveness is the set of institutions, policies, and factors that determine the level of productivity of an economy, which in turn sets the level of prosperity that the economy can achieve (Schwab, 2017). The World Economic Forum, which every year issues Global Competitiveness Report, uses Global Competitiveness Index (GCl) which combines 114 indicators grouped into 12 pillars: institutions, infrastructure, macroeconomic environment, health and primary education, higher education and training, goods market efficiency, labor market efficiency, financial market development, technological readiness, market size, business sophistication and innovation to estimate competitiveness of a nation (Schwab, 2017).

The $\mathrm{GCl}$ includes statistical data supplied by the International Monetary Fund (IMF), the World Bank and United Nations' specialized agencies, as well as indicators derived from the World Economic Forum's Executive Opinion Survey that reflect qualitative aspects of competitiveness (Schwab, 2017).

The focus of this study is on the position of BRICS countries (Brazil, Russia, India, China and South Africa) and Serbia in The Global Competitiveness Report for 2017 (Schwab, 2017).

BRICS countries have a population of about 3097.4 million inhabitants, while Serbia has a population of 7.0 million. BRICS country with the highest GDP of the US $\$ 11218.3$ billion is China, followed by India with the US $\$ 2256.4$ billion, Brazil with the US $\$ 1798.6$ billion, Russia with the US $\$ 1280.7$ billion and South Africa with GDP of US \$294.1 billion, while Serbia has a significantly lower GDP of US \$37.7 billion. Concerning the GDP per capita generated in 2016, Russia has the best result with the US $\$ 8928.7$, followed by Brazil with the US $\$ 8726.9$, China with the US $\$ 8113.3$, South Africa with the US $\$ 5260.9$ and India with the US \$1723.3. India has the lowest GDP per capita in BRICS group of countries, while South Africa has the lowest GDP and lowest number of inhabitants of 55.9 million. GDP per capita generated in Serbia in 2016 is the US \$5376.3, which is higher than in South Africa and India (Table 1).

Table 1. Data concerning population, GDP and GDP per capita for 2016

\begin{tabular}{|l|r|r|r|}
\hline Country & $\begin{array}{c}\text { Population } \\
\text { (million) }\end{array}$ & $\begin{array}{c}\text { GDP } \\
\text { (billion USD) }\end{array}$ & $\begin{array}{c}\text { GDP } \\
\text { per capita } \\
\text { (USD) }\end{array}$ \\
\hline Brazil & 206.1 & 1798.6 & 8726.9 \\
\hline Russia & 143.4 & 1280.7 & 8928.7 \\
\hline India & 1309.3 & 2256.4 & 1723.3 \\
\hline China & 1382.7 & 11218.3 & 8113.3 \\
\hline South & 55.9 & 294.1 & 5260.9 \\
\hline Africa & & 37.7 & 5376.3 \\
\hline Serbia & 7.0 & & \\
\hline
\end{tabular}

The table was made using (Schwab, 2017).

\section{COMPETITIVENESS OF BRICS COUNTRIES AND SERBIA}

If we examine the competitiveness of the BRICS countries and Serbia, according to The Global Competitiveness Report for 2017, we can conclude that Brazil has the lowest rank. Constraints are related to the public trust in politicians, the burden of government regulation and hiring and firing practices. There are poor indicators in the area of macroeconomic environment, goods market efficiency, labor market efficiency, institutions and health and primary education. The highest rank in this group of countries has China (27 ${ }^{\text {th }}$ place), followed by Russia ( $38^{\text {th }}$ place), India ( $40^{\text {th }}$ place), South Africa $\left(61^{\text {st }}\right.$ place $)$, Serbia $\left(78^{\text {th }}\right.$ place $)$ and Brazil $\left(80^{\text {th }}\right.$ place) (Table 2).

The position of Brazil has elevated by 1 position. It is ranked $80^{\text {th }}$, as opposed to last year when it was in $81^{\text {st }}$ position. According to The Global Competitiveness Report for 2017, the most problematic factors for doing business in Brazil are tax rates, restrictive labor regulations, corruption, inefficient government bureaucracy and inadequate supply of infrastructure. Brazil improved competitiveness position as a result of an increased capacity for innovation, a collaboration between universities and industry, a higher quality of research, and trained scientists and engineers (Schwab, 2017). 
Table 2. BRICS countries competitiveness rank 2013-2017 according to Global Competitiveness Report (number of ranked countries is given in brackets)

\begin{tabular}{|c|c|c|c|c|c|c|}
\hline Year / RC number & Brazil & Russia & India & China & South Africa & Serbia \\
\hline $\mathbf{2 0 1 3}(\mathbf{1 4 8})$ & 56 & 64 & 60 & 29 & 53 & 101 \\
\hline $\mathbf{2 0 1 4}(\mathbf{1 4 4})$ & 57 & 53 & 71 & 28 & 56 & 94 \\
\hline $\mathbf{2 0 1 5}(\mathbf{1 4 0})$ & 75 & 45 & 55 & 28 & 49 & 94 \\
\hline $\mathbf{2 0 1 6}(\mathbf{1 3 8})$ & 81 & 43 & 39 & 28 & 47 & 90 \\
\hline $\mathbf{2 0 1 7}(\mathbf{1 3 7})$ & 80 & 38 & 40 & 27 & 61 & 78 \\
\hline
\end{tabular}

The table was made using (Schwab, 2017).

Russia is on the $38^{\text {th }}$ position in the latest Report. Compared to the last year ranking, it progressed by 5 positions. The most problematic factors for doing business in Russia are corruption, tax rates, access to financing, inflation and tax regulations. Russia's economy is very dependent on mineral exports, while weak links also include the banking sector, the property rights, judicial independence, and corruption, which is still a problematic factor for doing business. Russia has increased the minimum wage and protects temporary employment, which lowered labor market flexibility by 18 places, but it may restore domestic purchasing power (Schwab, 2017).

India has regressed by 1 position compared to the last-year's report. It is in $40^{\text {th }}$ position. The most problematic factors for doing business in India have been identified as corruption, access to financing, tax rates, inadequate supply of infrastructure and poor work ethic in the national labor force. India's competitiveness improves in infrastructure, higher education, and training, as well as in technological readiness, as a result of government investments in these areas. Indicators in the area of information technology are also elevated, especially Internet bandwidth per user, mobile phone and broadband subscriptions, and Internet access in schools. Competitiveness of institutions has progressed because of public spending efficiency (Schwab, 2017).

China has progressed by 1 position compared to the last year and is now in $27^{\text {th }}$ position. The most problematic factors for doing business in China have been identified as access to financing, inefficient government bureaucracy, inflation, policy instability and corruption. China's largest improvement is in the area of technological readiness because foreign direct investments have been bringing new technologies to China. Also, there has been a reduction in the number of procedures for starting a business. But, there is a decline in the area of infrastructure as the result of a decline in the quality of port infrastructure and the reliability of electricity supply (Schwab, 2017).

The position of South Africa has deteriorated for 14 positions. It is ranked 61st, as opposed to last year when it was in $47^{\text {th }}$ position. According to The Global Competitiveness Report for 2017, the most problematic factors for doing business in South Africa are corruption, crime and theft, government instability, tax rates and inefficient government bureaucracy. South Africa is one of the most competitive and innovative countries in subSaharan Africa, although it regressed 14 positions. South Africa's economy is hit by persistently low international demand for its commodities and unemployment rate above 25 percent, while there is decreased confidence in business leaders (Schwab, 2017).

In Global Competitiveness Report for 2017, Serbia is ranked $78^{\text {th }}$ among 137 ranked countries, which is for 12 places higher since last year, when 138 countries were ranked and when it was on $90^{\text {th }}$ place. The most problematic factors for doing business in Serbia relate to tax rates, access to financing, inefficient government bureaucracy, corruption, and policy instability (Schwab, 2017).

\section{GCR INDICATORS RELATED TO SMES}

Global Competitiveness Report (GCR) indicators related to the small and medium enterprises (SMEs) can be found in $6^{\text {th }}$ pillar of competitiveness Goods market efficiency 
(effectiveness of anti-monopoly policy, number of procedures to start a business and number of days to start a business), in $7^{\text {th }}$ pillar of competitiveness Labor market efficiency (cooperation in laboremployer relations, flexibility of wage determination, hiring and firing practices, pay and productivity and reliance on professional management), in $9^{\text {th }}$ pillar of competitiveness Technological readiness (firm-level technology absorption) and in $11^{\text {th }}$ pillar of competitiveness Business sophistication (local supplier quantity, local supplier quality, state of cluster development, production process sophistication, extent of marketing and willingness to delegate authority).

According to the effectiveness of anti-monopoly policy, South Africa is on highest $28^{\text {th }}$ position, followed by China ( $30^{\text {th }}$ place), India (33rd place), Brazil (55 $5^{\text {th }}$ place), Russia ( $83^{\text {rd }}$ place) and Serbia (114 ${ }^{\text {th }}$ place). Russia has the lowest number of procedures to start a business, it is ranked $18^{\text {th }}$, followed by Serbia (36 $6^{\text {th }}$ place), South Africa $\left(70^{\text {th }}\right.$

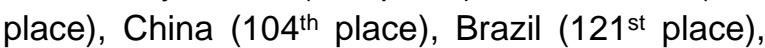
while India has the lowest rank - 131 st place. Serbia has the lowest number of days to start a business and it is on $40^{\text {th }}$ position, followed by

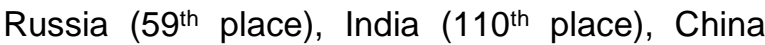
(116 ${ }^{\text {th }}$ place), South Africa (125 th place) and Brazil which is on $133^{\text {rd }}$ position. The best rank in cooperation in labor-employer relations has China ( $50^{\text {th }}$ place), followed by India ( $56^{\text {th }}$ place), Russia $\left(90^{\text {th }}\right.$ place $)$, Serbia $\left(105^{\text {th }}\right.$ place $)$, Brazil $\left(106^{\text {th }}\right.$ place) and South Africa (137 th place). Concerning flexibility of wage determination, Serbia has the highest rank and it is on $40^{\text {th }}$ position. Russia is ranked 88th, China $89^{\text {th }}$, India $104^{\text {th }}$, Brazil $121^{\text {st }}$ and South Africa $132^{\text {nd }}$. According to hiring and firing practices, India is ranked $19^{\text {th }}$, China $24^{\text {th }}$, Russia $46^{\text {th }}$, Serbia $80^{\text {th }}$, South Africa $125^{\text {th }}$ and Brazil $136^{\text {th }}$. China has the best rank according to pay and productivity and it is in $26^{\text {th }}$ place. India is ranked $33^{\text {rd }}$, Russia $57^{\text {th }}$, Serbia $68^{\text {th }}$, Brazil $89^{\text {th }}$ and South Africa 99th. South Africa has the highest rank also according to indicator reliance to professional management, it is on $43^{\text {rd }}$ place, followed by India ( $48^{\text {th }}$ place), Brazil (49th place), China ( $53^{\text {rd }}$ place), Russia ( $93^{\text {rd }}$ place) and Serbia $\left(128^{\text {th }}\right.$ place). Concerning firm-level technology absorption, South Africa ranks $38^{\text {th }}$, China $58^{\text {th }}$, Brazil $59^{\text {th }}$, Russia $72^{\text {nd }}$, India $73^{\text {th }}$ and Serbia $117^{\text {th }}$. According to local supplier quantity Brazil is $40^{\text {th }}$, South Africa $46^{\text {th }}$, China $52^{\text {nd }}$, India $53^{\text {rd }}$,
Russia $83^{\text {rd }}$ and Serbia $106^{\text {th }}$. According to local supplier quality, South Africa ranks $42^{\text {nd }}$, China $56^{\text {th }}$, Russia $66^{\text {th }}$, India $69^{\text {th }}$, Brazil $75^{\text {th }}$ and Serbia $79^{\text {th }}$. According to the state of cluster development China ranks the highest, it is on $27^{\text {th }}$ place, followed by South Africa (29th place), India (31 $1^{\text {st }}$ place), Brazil ( $41^{\text {st }}$ place), Russia $\left(88^{\text {th }}\right.$ place) and Serbia $\left(100^{\text {th }}\right.$ place). China is ranked $39^{\text {th }}$ concerning production process sophistication, followed by South Africa $\left(40^{\text {th }}\right)$, India $\left(41^{\text {st }}\right)$, Brazil $\left(62^{\text {nd }}\right)$, Russia $\left(64^{\text {th }}\right.$ place) and Serbia $\left(107^{\text {th }}\right)$. According to extent of marketing South Africa is on $30^{\text {th }}$ place, Brazil in $39^{\text {th }}$ place, China on $57^{\text {th }}$ place, Russia in $59^{\text {th }}$ place, India on the 61 st place and Serbia on $108^{\text {th }}$ place. Concerning willingness to delegate authority South Africa ranks $24^{\text {th }}$, India $45^{\text {th }}$, China $47^{\text {th }}$, Brazil $50^{\text {th }}$, Russia $80^{\text {th }}$ and Serbia $90^{\text {th }}$ place. China had the highest position among examined BRICS countries in terms of indicators related to the small and medium enterprises and Serbia should follow the example of China in the area of SMEs initiatives (Table 3).

Brazil has enhanced electronic data interchange system and made trading across borders easier by reducing the time needed for documentary compliance for exporting and importing (World Bank Group, 2018).

The Russian Federation made it easier to transfer property, get credit and increase competition by reducing the time needed to apply for state registration of title transfer by adopting a new law that establishes a modern collateral registry, by opening a new deepwater port on the coast of the Gulf of Finland and by reducing the cost of border compliance at the Port of St. Petersburg (World Bank Group, 2018).

India made starting a business faster by improving the online application system. Also, it reduced the number of procedures and time required to obtain a building permit by implementing an online system. India strengthened access to credit by amending the rules on the priority of secured creditors outside reorganization proceedings and by adopting a new law on insolvency that provides clear grounds for relief to the automatic stay for secured creditors during reorganization proceedings. India strengthened minority investor protections by increasing the remedies available in cases of prejudicial transactions and it made paying taxes easier by requiring that payments be 
made electronically and by introducing a set of administrative measures easing compliance with corporate income tax. Export and import border compliance costs were reduced by use of electronic and mobile platforms. India made resolving insolvency easier by introducing bankruptcy code that brought a reorganization procedure for corporate debtors and it has improved labor market regulation by increasing the mandatory length of paid maternity leave (World Bank Group, 2018)

China made starting a business paying taxes easier by streamlining registration procedures and introducing several measures to ease compliance (World Bank Group, 2018).

Serbia made starting a business, registering property and enforcing contracts easier by reducing the signature certification fee and increasing the efficiency of the registry, by improving reliability of its land administration system by implementing a geographic information system and by adopting a new enforcement law that broadens and clarifies the responsibilities of enforcement agents as well as the powers of the courts during the enforcement process (World Bank Group, 2018).

To increase its competitiveness, Serbia will have to improve the enterprise environment, digital agenda and education and training as a basis for smarter growth, but the priority will be to build the institutional capacity. Also, room for improvement is in the area of labor-employer relations and a high youth unemployment rate (Schwab, 2014). Youth and women in Serbia face obstacles to start and run their own small and medium enterprises, because of poor access to finance and lack of institutional support needed to achieve their full potential (Todorovic, Komazec, Jevtic, Obradovic, \& Maric, 2012).

Table 3: GCR Indicators related to SMES

\begin{tabular}{|l|c|c|c|c|c|c|}
\hline GCR Indicators & Brazil & Russia & India & China & South Africa & Serbia \\
\hline $\begin{array}{l}\text { Effectiveness of anti- } \\
\text { monopoly policy }\end{array}$ & 55 & 83 & 33 & 30 & 28 & 114 \\
\hline $\begin{array}{l}\text { No. of procedures to } \\
\text { start a business }\end{array}$ & 121 & 18 & 131 & 104 & 70 & 36 \\
\hline Time to start a business & 133 & 59 & 110 & 116 & 125 & 40 \\
\hline $\begin{array}{l}\text { Cooperation in labor- } \\
\text { employer relations }\end{array}$ & 106 & 90 & 56 & 50 & 137 & 105 \\
\hline $\begin{array}{l}\text { Flexibility of wage } \\
\text { determination }\end{array}$ & 121 & 88 & 104 & 89 & 132 & 40 \\
\hline $\begin{array}{l}\text { Hiring and firing } \\
\text { practices }\end{array}$ & 136 & 46 & 19 & 24 & 125 & 80 \\
\hline Pay and productivity & 89 & 57 & 33 & 26 & 99 & 68 \\
\hline $\begin{array}{l}\text { Reliance on professional } \\
\text { management }\end{array}$ & 49 & 93 & 48 & 53 & 43 & 128 \\
\hline $\begin{array}{l}\text { Firm-level technology } \\
\text { absorption }\end{array}$ & 59 & 72 & 73 & 58 & 38 & 117 \\
\hline Local supplier quantity & 40 & 83 & 53 & 52 & 46 & 106 \\
\hline Local supplier quality & 75 & 66 & 69 & 56 & 42 & 79 \\
\hline $\begin{array}{l}\text { State of cluster } \\
\text { development }\end{array}$ & 41 & 88 & 31 & 27 & 29 & 100 \\
\hline $\begin{array}{l}\text { Production process } \\
\text { sophistication }\end{array}$ & 62 & 64 & 41 & 39 & 40 & 107 \\
\hline Extent of marketing & 39 & 59 & 61 & 57 & 30 & 108 \\
\hline $\begin{array}{l}\text { Willingness to delegate } \\
\text { authority }\end{array}$ & 50 & 80 & 45 & 47 & 24 & 90 \\
\hline Mean value & 78 & 70 & 60 & 55 & 67 & 88 \\
\hline
\end{tabular}

Table was made using (Schwab, 2017) 


\section{CONCLUSIONS}

In the Global Competitiveness Report for 2017, the highest rank has China ( $27^{\text {th }}$ place), followed by Russia ( $38^{\text {th }}$ place), India ( $40^{\text {th }}$ place), South Africa (61 $1^{\text {st }}$ place), Serbia ( $78^{\text {th }}$ place) and Brazil $\left(80^{\text {th }}\right.$ place $)$. China's improvements are in technological readiness since foreign direct investments have been bringing new technologies to China, while China also reduced the number of procedures for starting a business. The decline is noticeable in the area of infrastructure as the result of a decline in the quality of port infrastructure and the reliability of electricity supply. Highest position among examined BRICS countries and Serbia in terms of indicators related to the small and medium enterprises has China, as a result of cluster development, hiring and firing practices and pay and productivity.

\section{WORKS CITED}

Savic, N. (2012). Comparative Analysis Based on New Competitiveness Index. Panoeconomicus, 1(2012), 105-115. Retrieved from doiSerbia: http://www.doiserbia.nb.rs/img/doi/1452595X/2012/1452-595X1201105S.pdf

Schwab, K. (2014). The Europe 2020 Competitiveness Report: Building a More Competitive Europe. Geneva: World Economic Forum. Retrieved from World Economic Forum: http://www3.weforum.org/docs/WEF_Europe2020_CompetitivenessReport_2014.pdf

Schwab, K. (2017). The Global Competitiveness Report 2017-2018. Geneva: World Economic Forum. Retrieved from World Economic Forum: http://www3.weforum.org/docs/GCR20172018/05FullReport/TheGlobalCompetitivenessReport2017\%E2\%80\%932018.pdf

Todorovic, I., Komazec, S., Jevtic, M., Obradovic V., \& Maric M. (2012). Strategic Management in Development of Youth and Women Entrepreneurship - Case of Serbia. Organizacija, 4(49), 197208. Retrieved from: file:///C:/Users/Dubravka/Downloads/Strategic_URN_NBN_SI_DOCE6RHQWCU.pdf

World Bank Group. (2018). Doing Business 2018: Reforming to Create Jobs. Washington DC: International Bank for Reconstruction and Development/The World Bank. Retrieved from Doing Business: http://www.doingbusiness.org/ /media/WBG/DoingBusiness/Documents/AnnualReports/English/DB2018-Full-Report.pdf

Received for publication: $\quad 03.02 .2018$

Revision received: $\quad 03.08 .2018$

Accepted for publication: 27.12 .2018

\section{How to cite this article?}

Style - APA Sixth Edition:

Skunca, D., Bogavac, M., \& Rudic, D. (2019, January 15). Competitiveness of Small and Medium Enterprises in the Brics Countries and Serbia. (Z. Čekerevac, Ed.) MEST Journal, 7(1), 92-98. doi:10.12709/mest.07.07.01.13 
Style - Chicago Sixteenth Edition:

Skunca, Dubravka, Milanka Bogavac, and Danilo Rudic. 2019. "Competitiveness of Small and Medium Enterprises in the Brics Countries and Serbia." Edited by Zoran Čekerevac. MEST Journal (MESTE) 7 (1): 92-98. doi:10.12709/mest.07.07.01.13.

Style - GOST Name Sort:

Skunca Dubravka, Bogavac Milanka and Rudic Danilo Competitiveness of Small and Medium Enterprises in the Brics Countries and Serbia [Journal] // MEST Journal / ed. Čekerevac Zoran. Belgrade - Toronto: MESTE, January 15, 2019. - 1: Vol. 7. - pp. 92-98. doi:10.12709/mest.07.07.01.13.

Style - Harvard Anglia:

Skunca, D., Bogavac, M. \& Rudic, D., 2019. Competitiveness of Small and Medium Enterprises in the Brics Countries and Serbia. MEST Journal, 15 January, 7(1), pp. 92-98.

Style - ISO 690 Numerical Reference:

Competitiveness of Small and Medium Enterprises in the Brics Countries and Serbia. Skunca, Dubravka, Bogavac, Milanka and Rudic, Danilo. [ed.] Zoran Čekerevac. 1, Belgrade - Toronto: MESTE, January 15, 2019, MEST Journal, Vol. 7, pp. 92-98. 